\title{
Uses Of New Media Before 2011 \\ By egyptian political Movements
}

\author{
By \\ Amen Said Abel-Ghany \\ Faculty of Specific Education \\ Mansoura University
}

\section{Research Joupnal Specific Education}

Faculty of Specific Education

Mansoura University

ISSUE NO. 27, OCTOBER. 2012

مجلة بحوث التربية النوعية ـ جامعة المنصورة

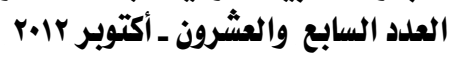




\title{
Uses of New Media Before 2011 By egyptian political Movements
}

\author{
Amen Said Abel-Ghany*
}

\section{Abstract}

This study examines the ability of new media to support democracy and play a role in changing Egypt as a model for developing countries. This is accomplished through studying the use of Egyptian political movements such as the "Kfaiya Movement", "April 6 Youth Movement" and "The National Assembly for Change". These movements used the new media to express their views, call others to participate in the activities they hold, and try to change the existing political system. This study surveyed a sample of these political movements members and Egyptian media specialists and revealed the ability of new tools for change and support democracy. At the same time, respondents affirmed the limited impact of these instruments in Egypt, because Egyptian political movements do not efficiently use the new media of communication, as $70 \%$ of the sample said that these movements "sometimes" do not use the new media efficiently.

*Faculty of Specific Education, Mansoura University 


\title{
Uses of NeW Media Before 2011 By egyptian political Movements
}

\author{
Amen Said Abel-Ghany"
}

\section{Introduction}

Researchers attached high hopes on new media in promoting democracy all over the world, and seeking to change human societies to the best. Though researchers monitored many cases where new media played an influential role, their hopes seem far away so far, especially in developing countries. This study examines the ability of new media to support democracy and play a role in changing Egypt as a model for developing countries. This is accomplished through studying the use of Egyptian political movements such as the "Kfaiya Movement", "April 6 Youth Movement" and "The National Assembly for Change". These movements used the new media to express their views, to call others to participate in the activities they hold, and to try to change the existing political system. This study surveyed a sample of these political movements members and Egyptian media specialists and revealed the ability of new tools for change and support democracy. At the same time, respondents affirmed the limited impact of these instruments in Egypt, because Egyptian political movements did not efficiently use the new media of communication sometimes, as $70 \%$ of the sample said. There are differences between the two elements of the sample-- media professionals and members of political movements. The respondents revealed several reasons for misuse of the new media and their limited impact. The most important of these reasons are:

1. Political reasons: including: network chasing, official violence pointed to change movements and trapping their activities in the street.

2. Social reasons such as: illiteracy, the ruling system of traditional values in these communities, the low educational level and high level of cultural illiteracy. In addition to the decline in using new media, as they are usually used by young people in developing societies, who are naturally not active, particularly in Arab societies, and only use them for recreational purposes.

* Faculty of Specific Education, Mansoura University 
3. Economic reasons such as poverty and lack of social justice in distributing wealth.

The study revealed that the majority of respondents affirmed that Egyptian political movements converted to electronic phenomena of confined and trapped in cyberspace. The same thing happened to Egyptian political parties which turned into, paper phenomena as they only exist through the newspapers. Only 25\% of the respondents said that Egyptian political movements did not convert to a digital phenomenon in confined cyberspaces, while $47 \%$ of them said that they converted to - some extent to a digital phenomenon and $27 \%$ said that they actually turned to a digital phenomena as political parties - formerly - into press phenomena.

\section{Literature Review}

The use of new media increased democratic participation by the otherwise apathetic masses in many places, but the means and results of the political use of new media are dissimilar. The American and Hong Kong civil societies cases both support several generalizations about how new media may increase participation in politics. First, they reduce frictions in political mobilization particularly in fund raising, voting and participation in protests. This is particularly useful at times of general discontent in the society. Second, they foster a sense of individual empowerment among citizens, thereby reducing political apathy. Third, so far political insurgents (those out of office or out of the mainstream) have more effectively experimented with alternative media than incumbents, who enjoy advantages in resources and access to the traditional mass media. Fourth, in election campaigns, the more competitive the race, the higher the incentives are for the candidates to explore creative use of digital media. 1

The Arabs started using new media heavily in 2003 in line the U.S. invasion of Iraq . the blogs were first and most important forms used in the Arab world, and became the blogging phenomenon in the Arab world in 2006.2 The distribution of Arabic blogs are not equal in terms of the number of Arab countries, where Egypt comes in the first place followed by Saudi Arabia and Kuwait, and Morocco. 3

The political implications come at the top of the topics offered in Arabic blogs, followed by social issues and religious subjects. Individual blogs far outnumber collective blogging. Bloggers use Arab Arabic basically. 4 


\section{Lynch says describes blogging activity this way:}

"Arab political bloggers engage in three principle types of activity: activism, bridge-blogging, and public sphere engagement. Activists are directly involved in political movements, using blogs to coordinate political action, spread information, and magnify the impact of contentious politics. Bridgebloggers primarily address Western audiences, usually writing in English with the intention of explaining their societies. Finally, public-sphere bloggers tend not to be directly involved in a political movement, but are deeply engaged with public arguments about domestic (and often Arab or Islamic) politics."5

There are many political movements and civil societies' organizations in Egypt since the year 2000 as:

The Egyptian Movement for Change "Kefaia":The Egyptian Movement for Change Kefaia is a collection of various Egyptian political bodies aimed at establishing a new legitimacy in Egypt, after getting rid of Hosni Mubarak's regime.

It started after the change of Egyptian cabinet in July 2004, when three hundred of Egyptian intellectuals and public figures representing the entire Egyptian political spectrum, wrote a document calls for real political change in Egypt and ending economic injustice and corruption in foreign policy. Kefaia followed the style of protest in most of its opposition situations against Egyptian regime which responded to the movement growth - that reached to 22 out of the 26 Egyptian governorates - with campaigns of detention and dragged that were described by the movement as savage. Kefaia won intense media support led by opposition newspapers, whose ceiling of freedom in what they are writing, raised because of Kefaia. Many journalists of those newspapers wrote almost daily about people they were banned to mention just before the emergence of this movement such as Egyptian President's family, especially his wife and his son Gamal Mubarak.6

Kefaia founded a website on the Internet, taking into account individual initiative and small group work, which brought great flexibility of movement at the same time accused of losing control of its internal events, they turned the stream of following-up events for the maker of the events in some situations, attitudes. The spread of the Egyptian Movement for Change Kefaia stimulated the emergence of other specific and class 
movements like "Youth for Change", "Workers for Change", and Journalists for Change" and "Students for change". Professional and freedom demands throughout Egypt went out of this movement as well as many others cadres and ideas used by the political parties and the Muslim Brotherhood in parallel activities. The movement called for a series of demonstrations on the Internet, namely:

- 12 December 2004 before the High Court in Cairo.

- 4 February 2005 at the Cairo Book Fair,

- 21 March 2005 in Cairo's Tahrir Square.

- 30 March 2005 in three governorates.

- 27 April 2005 in 15 governorates .

- 25 May 2005 on the referendum of the Constitution.

- 1 June 2005 at the Press Syndicate.

- 8 June 2005 in front of the tomb of Saad Zaghloul.

- 6 April 2008 as part of a call for a general strike in Egypt

\section{Kefaia Mandra:}

The Kefaia movement has a forum on the Internet, which is subordinate link from the movement official site and is considered as one of the strongest and best Egyptian political and cultural forums on the Internet which has thousands of participating members. Kefaia Mandra forum is characterized by its highly qualified members in culture and science, including many lawyers, journalists and writers, including a large number of bloggers and human rights activists. The Mandra site on the Internet is http://harakamasria.org/.7

\section{April Youth Movement:}

It is an Egyptian political opposition movement which emerged in 2008, created by some Egyptian youth after the Egyptian general strike April 6, 2008, as response to the call of the Mahalla textile workers and the solidarity of the political forces, and youth adopted it and began to call for a general strike all over Egypt. Most members of this movement are young people who do not belong to a specific trend or a political party and the movement is keen not to adopt certain ideology to preserve its ideological diversity and to achieve the need for unification and coalition and rejection of dispute. 
On 6 April 2008, some young people announced their solidarity with the strike of workers and adopted the idea of journalist Magdi Ahmed Hussein, who suggested the strike, should be in all Egypt, not only for workers. The movement began to make Facebook groups to spread the idea of the strike and send messages to Egyptian Facebook members (whose number reached to 70,000 in one group) calling for the strike. After a while some Egyptian newspapers talked about the strike idea and the movement and in a few days, messages randomly called for a general strike on 6 April.

\section{April Strike}

Some parties and Egyptian opposition movements responded to the idea of the strike such as Kefaia, the Muslim Brotherhood (withdrew later), Karama Party, El Wasat Party, the Labor Party, the movement of property taxes personnel, the movement of administrators and workers in education sector, Egyptian Lawyers Association and 9th of March Movement (known as movement universities professors) and some intellectuals and bloggers and online activists. In a short time, the idea of the strike spread in all parts of Egypt and was under the name "Stay at Home". It also called for demonstrations in several places in Cairo, Alexandria, and Mahalla. A number of its members were arrested after the implementation of the strike.

\section{The Alexandria March}

After the movement demonstrated outside the Press Syndicate in Cario, on June 28 2008, it appeared again in July 2008 and organized a march by some of the movement young people on the Corniche in the sea and one of Alexandria beaches, raised Egypt flags and sang some patriotic songs, but they were surprised by the siege of central security forces who arrested some of them, some other flew through the side streets in the area. 8

\section{The National Assembly For Change}

National Assembly for change is a loose grouping Egyptians from all various political and religious affiliations, including representatives of civil society and young people aims to change in Egypt, and for this there was general agreement for the need to unite all voices calling for change within a National Assembly asked Mohamed ElBaradei, to be the leader and support it, so that it becomes a general framework under which all voices calling for change can gather. 


\section{Objectives of the Assembly}

The main objective of the Assembly is working to reach a political system based on actual democracy and social justice. The first achieve this is to ensure basic guarantees for free and fair elections involving all Egyptians, to provide an equal opportunity for all, in either legislative or presidential elections. This is a part of guarantees and procedures sought by broad categories of Egyptian society for many years, particularly:

1. Ending the state of emergency.

2. Enabling Egyptian judiciary to have full control on the whole electoral process.

3. Supervising electoral process by the local civil society and international organizations

4. Providing equal opportunities in the media for all candidates, especially in presidential election.

5. Enabling Egyptians abroad to exercise their right to vote in Egyptian embassies and consulates.

6. Ensuring the right of candidature in the presidential election without arbitrary restrictions in line with Egypt's obligations to the International Convention for Civil and Political Rights, and limiting the right of candidature for the presidency to two terms.

7. Voting by the national ID.9

\section{Assembly Demands}

1. Modifying Article 76 of the Egyptian Constitution.

2. Modifying Article 77 of the Egyptian Constitution which states that "Presidency term is six calendar years starting from the date of announcing the referendum results, and president may be re-elected for another term.

3. Modifying Article 88 of the Egyptian Constitution which states that "The law defines the conditions to be found in members of People Assembly, shows the rules of election and referendum, voting takes place in one day. A supreme independent fair committee supervises election, as regulated by law, which specifies the responsibilities of the committee, the method of formation and guarantees of its members, provided that it should involve, current and former members of judicial bodies,. This supreme committee is responsible for establishing general committees, which oversee elections in all electoral districts, committees which exercise the voting procedures 
and sorting committees, provided that general committees should be established from the members of judicial bodies, and that sorting process must be done under the supervision of general committees, and all this must be done according to the rules and procedures prescribed by law. "10

\section{Hypotheses.}

H1: There are statistically significant differences between political movements' members and media specialists in the efficient use of new media.

H2: There are statistically significant differences between political movements' members and media specialists in the effectiveness of new media.

H3: There are statistically significant differences between political movements' members and media specialists in the ability of new media means in making change in developing countries.

\section{Method}

The study has an intentional sample of (100) media specialists (journalists - university professors, media researchers) and (100) members of political movements.

- A field study was applied on specialists and political movements' members to discuss:

- Uses and forms of new media by Egyptian political movements.

- The direct results in the short term from uses of new media by Egyptian political movements.

- Expected Results on the long-term from uses of new media by Egyptian political movements.

- Opportunities for making change through these media in developing societies such as Egypt.

- The relation between new media and information curtain (do they unfold information curtain? Or would they make their own curtain?)

\section{This study used a questionnaire composed of five dimensions:}

1. Using new media by political movements.

2. Evaluating Egyptian political movements' use of the new media.

3. The possibility of achieving change of reality through using new media. 


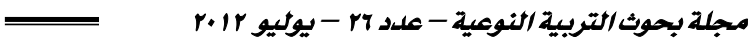

4. The political movements' future use of the new media.

5. Respondents' data.

The questionnaire was administrated from March 2010 until May 2010 by direct interview with the respondents.

The preliminary form of the questionnaire was judged by 10 referees specialized in new media research and research methodology to examine its validity. Referees' remarks were gathered and used in developing the final form of the questionnaire.

Analysis reliability was measured by re-analyzing one fourth of the questionnaire. The reliability coefficient between the two analyses was .96.

\section{Results}

The order of new media as used by Egyptian political movements

Egyptian political movements depend on blogs, websites, chat rooms and e-mail more than forums, audio and video materials, SMS, online advertising, or telephone and web cams details as follows:

According to the specialists' opinion, the order of communication media used by political movements was as follows: blogging came in the first place, followed by websites, e-mail, chat rooms, online advertising, forums, audio and video materials, online telephone, SMS, virtual reality techniques, and at last web cams.

According to the movements members' opinion, the order of communication media used by political movements was as follows:, blogging was in the first place, then websites, chat rooms, e-mail, audio and video materials, forums, SMS, virtual reality techniques, online advertising, online telephone, and at last webcams.

According to the total sample's opinion, the order of communication media used by political movements was as follows: blogging came in the first place, then websites, chat rooms, e-mail, forums, audio and video materials, SMS, online advertising, virtual reality techniques, online telephone, and at last webcams. 
Table 1

New Media Order According to Use by Political Movements

\begin{tabular}{|c|c|c|c|c|c|c|}
\hline & \multicolumn{4}{|c|}{ Sample } & \multirow{2}{*}{\multicolumn{2}{|c|}{ Total }} \\
\hline & \multicolumn{2}{|c|}{ Specialists } & \multicolumn{2}{|c|}{ Movements Members } & & \\
\hline & $\#$ & Order & \# & order & $\#$ & order \\
\hline blogs & 409 & 1 & 295 & 1 & 704 & 1 \\
\hline e-mail & 509 & 3 & 477 & 4 & 986 & 4 \\
\hline Online advertising & 563 & 5 & 789 & 9 & 1352 & 8 \\
\hline websites & 439 & 2 & 433 & 2 & 872 & 2 \\
\hline Online telephone & 663 & 8 & 887 & 10 & 1550 & 10 \\
\hline web cams & 831 & 11 & 889 & 11 & 1720 & 11 \\
\hline $\begin{array}{l}\text { virtual reality } \\
\text { technologies }\end{array}$ & 758 & 10 & 670 & 8 & 1428 & 9 \\
\hline chat rooms & 520 & 4 & 476 & 3 & 996 & 3 \\
\hline forums & 573 & 6 & 534 & 6 & 1107 & 5 \\
\hline SMS & 674 & 9 & 667 & 7 & 1341 & 7 \\
\hline $\begin{array}{c}\text { audio and video } \\
\text { materials }\end{array}$ & 661 & 7 & 483 & 5 & 1144 & 6 \\
\hline
\end{tabular}

\section{New Media Order According to Use by Political Movements}

The nature of the Egyptian political movements and their relation to new media $29 \%$ of respondents saw a link between the Egyptian political movements and new media, and agreed that these movements are the result of new media, while $62 \%$ of them stress that these movements use these media and rely on them in continuing their activities, this can be noticed as follows:

Of the specialists, $66 \%$ said the Egyptian political movements use new media, and 53\% said that Egyptian political movements imitate global movements. Also, 45\% said that Egyptian political movements are the secretion of the Egyptian reality, while 34\% said that Egyptian political movements are results of new media of communication. See Table 2.

Of the movements members, $84 \%$ said that Egyptian political movements are the secretion of the Egyptian reality, 58\% said that these movements use new media, 24\% said that Egyptian political movements are results of new media of communication and 19\% said that Egyptian political movements imitate global movements.

Sixty-four percent of the respondents said that Egyptian political movements are the secretion of the Egyptian reality, and $62 \%$ of them said 
that these movements use new media. Thirty-six percent said that Egyptian political movements imitate global movements, while only $29 \%$ said that Egyptian political movements are results of new media of communication, as Table 2 indicates.

Table 2

Nature of the Egyptian Political Movements andTheir Relation to New Media

\begin{tabular}{|c|c|c|c|c|c|c|}
\hline & \multicolumn{4}{|c|}{ Sample } & \multirow{2}{*}{\multicolumn{2}{|c|}{ Total }} \\
\hline & \multicolumn{2}{|c|}{ Specialists } & \multicolumn{2}{|c|}{$\begin{array}{c}\text { Movements } \\
\text { Members }\end{array}$} & & \\
\hline & $\#$ & $\%$ & $\#$ & $\%$ & $\#$ & $\%$ \\
\hline $\begin{array}{c}\text { are results of } \\
\text { new media of } \\
\text { communication }\end{array}$ & 34 & $34.00 \%$ & 24 & $24.00 \%$ & 58 & $29.00 \%$ \\
\hline Use new media & 66 & $66.00 \%$ & 58 & $58.00 \%$ & 124 & $62.00 \%$ \\
\hline $\begin{array}{l}\text { imitate global } \\
\text { movements }\end{array}$ & 53 & $53.00 \%$ & 19 & $19.00 \%$ & 72 & $36.00 \%$ \\
\hline $\begin{array}{l}\text { secretion of the } \\
\text { Egyptian reality }\end{array}$ & 54 & $45.00 \%$ & 84 & $84.00 \%$ & 129 & $64.50 \%$ \\
\hline Total & 100 & $100 \%$ & 100 & $100,00 \%$ & 200 & $100,00 \%$ \\
\hline & & chi-so & $=2$ & & & \\
\hline
\end{tabular}

$\chi^{2}=7.82, . \mathrm{p}<0.05$

\section{Nature of the Egyptian Political Movements and Their Relation to New Media}

Cases occurred in reality as a result of Egyptian political movement's use of the new media. The study sample affirms that 12 real cases occurred as a result of Egyptian political movement's use of the new media.

Table 3 shows $29.7 \%$ of the specialists said sit-ins and protests were main use in reality of use of new media, $22.0 \%$ said participation in elections was main sue and $12.2 \%$ said paying attention to issues defended by the movements and the emergence of new movements was main use.

Table 3 also shows movements members had a different perspective with $33.9 \%$ saying said sit-ins and protests were main use in reality, $25.0 \%$ said sit-ins and demonstrations in the recent period was main use and $10.7 \%$ said the support of some political figures was main use.

According to $31.9 \%$ the total sample, main use was sit-ins and protests, while $15.5 \%$ said the response to most sit-ins and demonstrations 
in the recent period was main use and $9.3 \%$ said participation in elections and the emergence of new movements was main use, as Table 3 shows.

Table 3

Uses Occurred in Reality as Result of Egyptian Political Movement's Use of New Media

\begin{tabular}{|c|c|c|c|c|c|c|}
\hline \multirow{3}{*}{ Media } & \multicolumn{4}{|c|}{ Sample } & \multirow{2}{*}{\multicolumn{2}{|c|}{ Total }} \\
\hline & \multicolumn{2}{|c|}{ Specialists } & \multicolumn{2}{|c|}{$\begin{array}{l}\text { Movements } \\
\text { Members }\end{array}$} & & \\
\hline & $\#$ & $\%$ & $\#$ & $\%$ & $\#$ & $\%$ \\
\hline $\begin{array}{c}\text { paying attention to issues } \\
\text { defended by the movements }\end{array}$ & 5 & $12.20 \%$ & 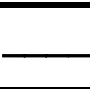 & 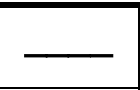 & 5 & $5.15 \%$ \\
\hline $\begin{array}{l}\text { response to most recent sit-ins } \\
\text { and demonstrations }\end{array}$ & 1 & $2.44 \%$ & 14 & $25.00 \%$ & 15 & $15.46 \%$ \\
\hline Sit-ins and protests & 12 & $29.27 \%$ & 19 & $33.93 \%$ & 31 & $31.96 \%$ \\
\hline participation in elections & 9 & $21.95 \%$ & 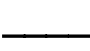 & - & 9 & $9.28 \%$ \\
\hline $\begin{array}{l}\text { support of some political } \\
\text { figures }\end{array}$ & 1 & $2.44 \%$ & 6 & $10.71 \%$ & 7 & $7.22 \%$ \\
\hline constitutional amendments & 3 & $7.32 \%$ & 3 & $5.36 \%$ & 6 & $6.19 \%$ \\
\hline $\begin{array}{l}\text { freedom practised by those } \\
\text { groups in presenting topics }\end{array}$ & 2 & $4.88 \%$ & & & 2 & $2.06 \%$ \\
\hline emergence of new movements & 5 & $12.20 \%$ & 4 & $7.14 \%$ & 9 & $9.28 \%$ \\
\hline $\begin{array}{c}\text { public response to these } \\
\text { movements }\end{array}$ & 3 & $7.32 \%$ & 2 & $3.57 \%$ & 5 & $5.15 \%$ \\
\hline issuing voting cards & 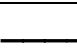 & 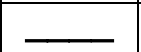 & 1 & $1.79 \%$ & 1 & $1.03 \%$ \\
\hline $\begin{array}{c}\text { spreading awareness and } \\
\text { contributing to problems } \\
\text { access to the media and } \\
\text { officials }\end{array}$ & & & 5 & $8.93 \%$ & 5 & $5.15 \%$ \\
\hline $\begin{array}{l}\text { judges supervision of the } \\
\text { previous elections }\end{array}$ & & & 2 & $3.57 \%$ & 2 & $2.06 \%$ \\
\hline Total & 41 & $100,00 \%$ & 56 & $100,00 \%$ & 97 & $100,00 \%$ \\
\hline & Chi- & uare $=39$. & & & & \\
\hline
\end{tabular}

$\chi^{2}=19.68, . \mathrm{p}<0.05$

\section{Uses Occurred in Reality as Result of Egyptian Political Movement's Use of New Media}

Members of the study sample identified 23 causes of making no change, in Egyptian reality, despite Egyptian political movements' use of new media, some reasons are related to the ruling regime, others belong to the nature of society and reasons related to the movements, its nature and efficiency of their use of new media, details as follows: 

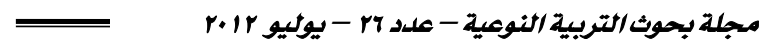

Table 4 indicates $15.9 \%$ of the specialists said Egyptian political movements seeking personal purposes and interests was main reason for absence of change despite use of new media, while 11.4 said these movements do not reflect or represent the reality. Three reasons change does not occur are cited by $9.1 \%$.

Table 4 shows $38.1 \%$ of the movements members said absence was change was because these movements are suppressed and controlled by the state security, while $19.0 \%$ said it was because change does not stem from these movements and $14.3 \%$ said it was because of the absence of the public will for change and the lack of solidarity on behave of a wide range of people.

Of the total sample $12.3 \%$ said absence of change was because those movements are suppressed and controlled by the state security, while $12.3 \%$ said it was because they seek personal purposes and interests and $10.8 \%$, said it was because these movements do not reflect or represent the reality. 
Table 4

Causes of No Change in Spite of Egyptian Political Movements' Use of New Media

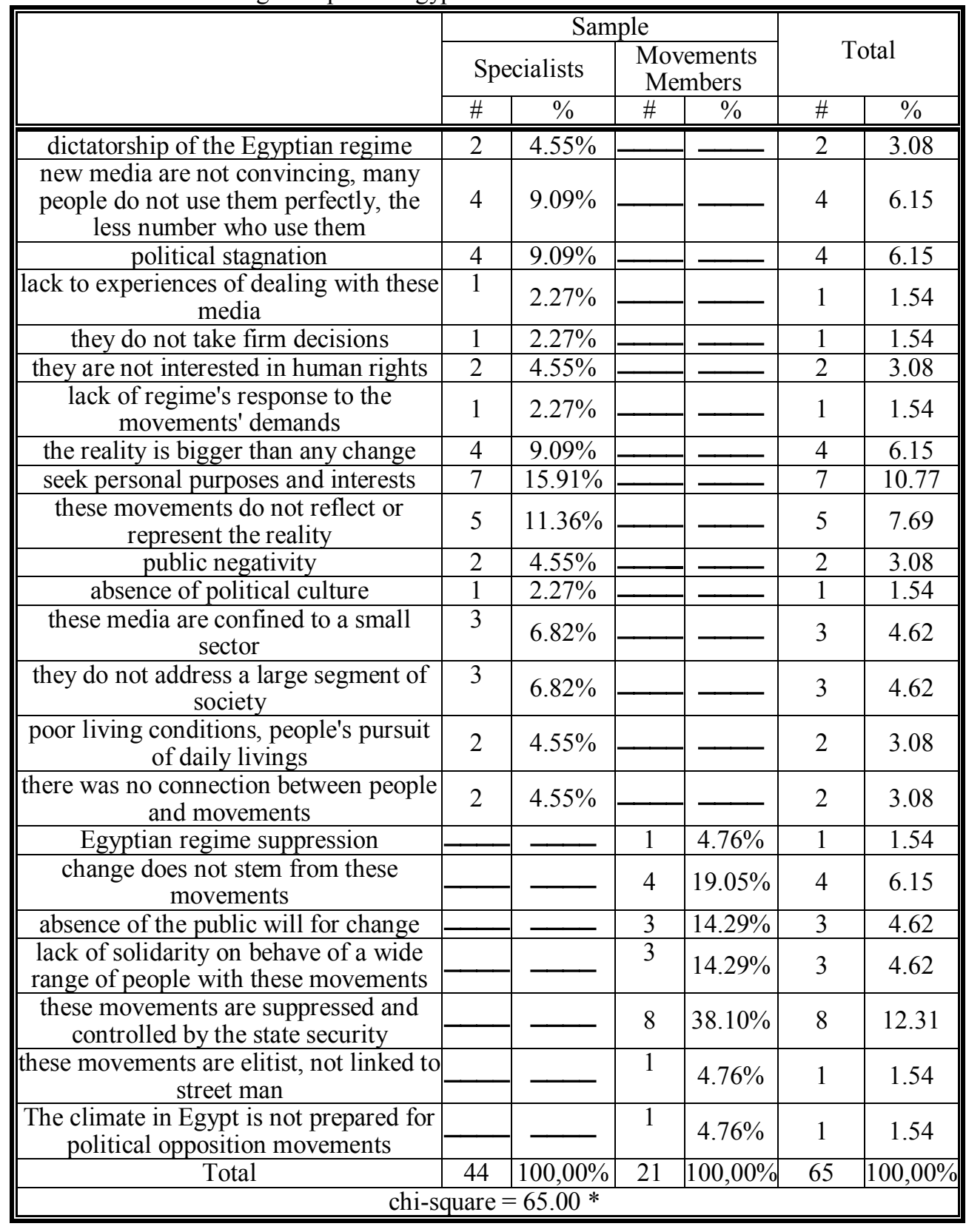

$\chi 2=33.92, . \mathrm{p}<0.05$ 
$\overline{\underline{ }}$

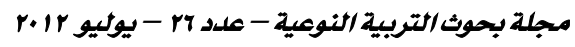

Causes of No Change in Spite of Egyptian Political Movements' Use of New Media

Respondents identified 37 changes that can happen in the future if Egyptian political movements more efficiently use new media, as follows:

In first place, $11.1 \%$ of the specialists put scattering society into groups and categories and public response to the calls of movements. Youth political participation, freedom of thought and opinion, and public awareness of the reality and the possibility of mobilizing them with a percentage were cited by $8.3 \%$. Political mobilization, having an active role in political life, improving the country in all aspects of life, creating a public compressing opinion for change, participation of Egyptians abroad and the disappearance of traditional media were cited by $5.6 \%$.

In first place, movements members put changing ruling regime with a percentage of $13 \%$, followed by public awareness of the reality and the possibility of mobilizing them with a percentage of $11.1 \%$. Then youth political participation, creating a public compressing opinion for change, modifying some articles of the Constitution were cited by $7.4 \%$. Raising political awareness, emergence of new movements, increasing margin of freedom, cancellation of emergency law, enlightening public with rights and interests, more courage in protests and national and international with movements were cited by $5.6 \%$, as Table 5 indicates.

In first place, total sample put public awareness of the reality and the possibility of mobilizing them with a percentage of $10 \%$, followed by freedom of thought and opinion with a percentage of $8.9 \%$ and youth political participation and changing ruling regime with a percentage of $78 \%$. 
Table 5

Changes That Can Occur in Future Reality, When Egyptian Political Movements Use New Means

\begin{tabular}{|c|c|c|c|c|c|c|}
\hline & \multicolumn{4}{|c|}{ Sample } & \multirow{2}{*}{\multicolumn{2}{|c|}{ Total }} \\
\hline & \multicolumn{2}{|c|}{ Specialists } & \multicolumn{2}{|c|}{$\begin{array}{l}\text { Movements } \\
\text { Members }\end{array}$} & & \\
\hline & $\#$ & $\%$ & $\#$ & $\%$ & $\#$ & $\%$ \\
\hline Electronic nominating and voting & 1 & $2.78 \%$ & & $\overline{-}$ & $\overline{1}$ & $1.11 \%$ \\
\hline $\begin{array}{c}\text { scattering society into groups and } \\
\text { categories }\end{array}$ & 4 & $11.11 \%$ & & & 4 & $4.44 \%$ \\
\hline $\begin{array}{l}\text { response to public demands such as } \\
\text { raising wages }\end{array}$ & 1 & $2.78 \%$ & & & 1 & $1.11 \%$ \\
\hline $\begin{array}{c}\text { public response to the calls of } \\
\text { movements }\end{array}$ & 4 & $11.11 \%$ & & & 4 & $4.44 \%$ \\
\hline $\begin{array}{l}\text { existence of public opinion about many } \\
\text { issues }\end{array}$ & 1 & $2.78 \%$ & & & 1 & $1.11 \%$ \\
\hline youth political participation & 3 & $8.33 \%$ & 4 & $7.41 \%$ & 7 & $7.78 \%$ \\
\hline freedom of thought and opinion & 3 & $8.33 \%$ & 5 & $9.26 \%$ & 8 & $8.89 \%$ \\
\hline political mobility & 2 & $5.56 \%$ & & & 2 & $2.22 \%$ \\
\hline $\begin{array}{l}\text { existence of new figures and increasing } \\
\text { their political popularity }\end{array}$ & 1 & $2.78 \%$ & & & 1 & $1.11 \%$ \\
\hline spreading political ideas & 1 & $2.78 \%$ & & & 1 & $1.11 \%$ \\
\hline having an active role in political life & 2 & $5.56 \%$ & & & 2 & $2.22 \%$ \\
\hline $\begin{array}{l}\text { raising political awareness and } \\
\text { emergence of new movements }\end{array}$ & 1 & $2.78 \%$ & 3 & $5.56 \%$ & 4 & $4.44 \%$ \\
\hline $\begin{array}{l}\text { increasing number of these media users } \\
\text { may change future reality }\end{array}$ & 1 & $2.78 \%$ & & & 1 & $1.11 \%$ \\
\hline $\begin{array}{c}\text { improving the country in all aspects of } \\
\text { life }\end{array}$ & 2 & $5.56 \%$ & & & 2 & $2.22 \%$ \\
\hline $\begin{array}{c}\text { creating a public compressing opinion for } \\
\text { change }\end{array}$ & 2 & $5.56 \%$ & 4 & $7.41 \%$ & 6 & $6.67 \%$ \\
\hline participation of Egyptians abroad & 2 & $5.56 \%$ & & & 2 & $2.22 \%$ \\
\hline $\begin{array}{l}\text { public awareness of the reality and the } \\
\text { possibility of mobilizing them }\end{array}$ & 3 & $8.33 \%$ & 6 & $11.11 \%$ & 9 & $10.00 \%$ \\
\hline disappearance of traditional media & 2 & $5.56 \%$ & & & 2 & $2.22 \%$ \\
\hline spreading awareness and freedoms & & & 2 & $3.70 \%$ & 2 & $2.22 \%$ \\
\hline $\begin{array}{l}\text { ease and quickness of distributing } \\
\text { information and documents }\end{array}$ & & & 2 & $3.70 \%$ & 2 & $2.22 \%$ \\
\hline public quicker communication & & & 5 & $9.26 \%$ & 5 & $5.56 \%$ \\
\hline changing ruling regime & & & 7 & $12.96 \%$ & 7 & $7.78 \%$ \\
\hline $\begin{array}{l}\text { increasing margin of freedom, } \\
\text { cancellation of emergency law }\end{array}$ & & & 3 & $5.56 \%$ & 3 & $3.33 \%$ \\
\hline $\begin{array}{l}\text { modifying some articles of the } \\
\text { Constitution }\end{array}$ & & & 4 & $7.41 \%$ & 4 & $4.44 \%$ \\
\hline $\begin{array}{c}\text { enlightening public with rights and } \\
\text { interests }\end{array}$ & & & 3 & $5.56 \%$ & 3 & $3.33 \%$ \\
\hline $\begin{array}{l}\text { more courage in protests and national } \\
\text { and international with movements }\end{array}$ & & & 3 & $5.56 \%$ & 3 & $3.33 \%$ \\
\hline $\begin{array}{l}\text { presidency nominating and using these } \\
\text { media in propagation }\end{array}$ & & & 1 & $1.85 \%$ & 1 & $1.11 \%$ \\
\hline attaining more freedom by media & & & 2 & $3.70 \%$ & 2 & $2.22 \%$ \\
\hline Total & 36 & $100,00 \%$ & 54 & $100,00 \%$ & 90 & $100,00 \%$ \\
\hline & & & & & & \\
\hline
\end{tabular}

$\chi^{2}=40.11, . \mathrm{p}<0.05$ 
Changes That Can Occur in Future Reality, When Egyptian Political Movements Use New Means

Respondents identified 17 cases changes that can happen in the future when Egyptian political movements use new media, as Table 6 shows.

In first place, $34.9 \%$ of specialists identified constitutional amendments . Next came responding to some of the demonstrations and political participation cited by $16.3 \%$, followed by knowing of citizens' rights and duties and freedom of opinion and expression cited by $9.3 \%$.

Top pick by movements members was Baradei campaign on Facebook cited by $11.8 \%$, followed by constitutional amendments, knowing of citizens' rights and duties, making individuals aware with reality and more political mobility that could lead to public pressure to improve life conditions cited by $8.8 \%$.

However, the total sample identified constitutional amendments as first with a percentage of $23.4 \%$, followed by responding to some of the demonstrations and political participation knowing of citizens' rights and duties cited by $9.1 \%$.

Table 6

Cases Which Can Occur in Future Reality When Egyptian Political Movements Use New Media

\begin{tabular}{|c|c|c|c|c|c|c|}
\hline & \multicolumn{4}{|c|}{ Sample } & \multirow{2}{*}{\multicolumn{2}{|c|}{ Total }} \\
\hline & \multicolumn{2}{|c|}{ Specialists } & \multicolumn{2}{|c|}{$\begin{array}{l}\text { Movements } \\
\text { Members }\end{array}$} & & \\
\hline & \# & $\%$ & \# & $\%$ & \# & $\%$ \\
\hline constitutional amendments & 15 & $34.88 \%$ & 3 & $8.82 \%$ & 18 & $23.38 \%$ \\
\hline responding to some of the demonstrations & 7 & $16.28 \%$ & & & 7 & $9.09 \%$ \\
\hline political participation & 7 & $16.28 \%$ & & & 7 & $9.09 \%$ \\
\hline positive participation of masses & 3 & $6.98 \%$ & & & 3 & $3.90 \%$ \\
\hline knowing of citizens' rights and duties & 4 & $9.30 \%$ & 3 & $\overline{8.82 \%}$ & 7 & $9.09 \%$ \\
\hline freedom of opinion and expression & 4 & $9.30 \%$ & & & 4 & $5.19 \%$ \\
\hline strikes and sit-ins & 3 & $6.98 \%$ & 2 & $\overline{5.88 \%}$ & 5 & $6.49 \%$ \\
\hline making individuals aware with reality & & & 3 & $8.82 \%$ & 3 & $3.90 \%$ \\
\hline increasing wages & & $\overline{-}$ & 2 & $5.88 \%$ & 2 & $2.60 \%$ \\
\hline Baradei campaign on Facebook & & & 4 & $11.76 \%$ & 4 & $5.19 \%$ \\
\hline changing some articles of the emergency law & & & 2 & $5.88 \%$ & 2 & $2.60 \%$ \\
\hline increasing the number of these media users & & & 2 & $5.88 \%$ & 2 & $2.60 \%$ \\
\hline some officials accountability & & & 1 & $2.94 \%$ & 1 & $1.30 \%$ \\
\hline abolition of emergency law & & & 1 & $2.94 \%$ & 1 & $1.30 \%$ \\
\hline $\begin{array}{l}\text { quota (seats for women in the People } \\
\text { Assembly) }\end{array}$ & & & 2 & $5.88 \%$ & 2 & $2.60 \%$ \\
\hline mobilization of public opinion & & & 1 & $2.94 \%$ & 1 & $1.30 \%$ \\
\hline more political mobility & & & 3 & $8.82 \%$ & 3 & $3.90 \%$ \\
\hline $\begin{array}{l}\text { lead to public pressure to improve life } \\
\text { conditions }\end{array}$ & & & 3 & $8.82 \%$ & 3 & $3.90 \%$ \\
\hline $\begin{array}{c}\text { Increasing awareness of the importance of } \\
\text { change }\end{array}$ & & & 2 & $5.88 \%$ & 2 & $2.60 \%$ \\
\hline Total & 43 & $100,00 \%$ & 34 & $100,00 \%$ & 77 & $100,00 \%$ \\
\hline chi-square & & & & & & \\
\hline
\end{tabular}

$\chi 2=28.87, . p<0.05$ 
Cases Which Can Occur in Future Reality When Egyptian Political Movements Use New Media

Respondents mentioned 17 reasons for the transformation of the Egyptian political movements to digital phenomena confined in cyberspace. Political parties formerly turned to press phenomena.

Table 7 shows the first reason specialists cited was that those movements do not seek the interests of society cited by $23.1 \%$. Another $12.8 \%$ said they do not actually exist, while 7.7 said they are not sufficiently effective, their impact on reality is not clear, and lack of public awareness.

Movements members put illiteracy, poverty and security chases first with a percentage of $33.3 \%$, followed by $26.7 \%$ who said restrictions put on the movements were the reason and $20 \%$ who said many negative techniques used to express themselves, like demonstrations, etc. with a percentage of $20 \%$. was the reason.

Table 8 shows some specialists $(15.6 \%)$ think that digital phenomena of those movements are confined to cyberspace is that they are not actually on the ground while $13.3 \%$ believe they only depend on electronic media and $8.9 \%$ think they are confined to certain categories and segments and do not represent the rest of society.

One fifth of the movements members said restrictions re the reason for this, while $14 \%$ said it was because movements are not actually on the ground and $12 \%$ said security checks were main reason.

Of the total sample, $14.7 \%$ said those movements are not found in reality $10.5 \%$ cited restrictions on them with as a percentage of and $9.5 \%$ said they only depend on electronic media. 
Table 7

Reasons for the Transformation of the Egyptian Political Movements to Digital Phenomena Confined in Cyberspace"Sometimes"

\begin{tabular}{|c|c|c|c|c|c|c|}
\hline & \multicolumn{4}{|c|}{ Sample } & \multirow{2}{*}{\multicolumn{2}{|c|}{ Total }} \\
\hline & \multicolumn{2}{|c|}{ Specialists } & \multicolumn{2}{|c|}{$\begin{array}{l}\text { Movements } \\
\text { Members }\end{array}$} & & \\
\hline & \# & $\%$ & $\#$ & $\%$ & \# & $\%$ \\
\hline $\begin{array}{l}\text { those movements are not actually on the } \\
\text { ground }\end{array}$ & 7 & $15.56 \%$ & 7 & $14.00 \%$ & 14 & $14.74 \%$ \\
\hline $\begin{array}{l}\text { lack of traditional media interest in those } \\
\text { movements }\end{array}$ & & & 1 & $2.00 \%$ & 1 & $1.05 \%$ \\
\hline restrictions on those movements & & & 10 & $20.00 \%$ & 10 & $10.53 \%$ \\
\hline weak and simple effect & & & 4 & $8.00 \%$ & 4 & $4.21 \%$ \\
\hline $\begin{array}{l}\text { lack of real freedom which is confined to } \\
\text { the Internet }\end{array}$ & & & 3 & $6.00 \%$ & 3 & $3.16 \%$ \\
\hline $\begin{array}{l}\text { security chases, and are confined to a } \\
\text { limited number of Internet users }\end{array}$ & & & 6 & $12.00 \%$ & 6 & $6.32 \%$ \\
\hline they only depend on electronic media & 6 & $13.33 \%$ & 3 & $6.00 \%$ & 9 & $9.47 \%$ \\
\hline $\begin{array}{l}\text { low level of youth political awareness, } \\
\text { repression by the regime }\end{array}$ & 1 & $2.22 \%$ & 3 & $6.00 \%$ & 4 & $4.21 \%$ \\
\hline $\begin{array}{l}\text { They are not confined to cyberspace but } \\
\text { also spread to the rest of the media and the } \\
\text { Egyptian street }\end{array}$ & & & 2 & $4.00 \%$ & 2 & $2.11 \%$ \\
\hline $\begin{array}{l}\text { The influence of those movements that } \\
\text { formerly came down to the street did not } \\
\text { remain longer }\end{array}$ & & & 2 & $4.00 \%$ & 2 & $2.11 \%$ \\
\hline $\begin{array}{l}\text { they are confined to certain categories and } \\
\text { segments and do not represent the rest of } \\
\text { society }\end{array}$ & 4 & $8.89 \%$ & 4 & $8.00 \%$ & 8 & $8.42 \%$ \\
\hline $\begin{array}{c}\text { they did not show any serious moves } \\
\text { towards change }\end{array}$ & & & 4 & $8.00 \%$ & 4 & $4.21 \%$ \\
\hline $\begin{array}{l}\text { negativity of most citizens and the lack of a } \\
\text { suitable climate for oppose the regime }\end{array}$ & & & 1 & $2.00 \%$ & 1 & $1.05 \%$ \\
\hline they're widespread among young people & 2 & $4.44 \%$ & & & 2 & $2.11 \%$ \\
\hline $\begin{array}{c}\text { The absence of democracy and freedom of } \\
\text { opinion }\end{array}$ & 1 & $2.22 \%$ & & & 1 & $1.05 \%$ \\
\hline Do not know exactly & 2 & $4.44 \%$ & & & 2 & $2.11 \%$ \\
\hline some movements seek fame & 1 & $2.22 \%$ & & & 1 & $1.05 \%$ \\
\hline $\begin{array}{l}\text { and the dominance and control of the ruling } \\
\text { party, they are satisfied only with protest }\end{array}$ & 2 & $4.44 \%$ & & & 2 & $2.11 \%$ \\
\hline $\begin{array}{l}\text { they are not sufficiently effective, their } \\
\text { impact on reality is not clear }\end{array}$ & 3 & $6.67 \%$ & & & 3 & $3.16 \%$ \\
\hline Do not reflect the opinion of the people & 3 & $6.67 \%$ & & & 3 & $3.16 \%$ \\
\hline Do not interfere in individuals concerns & 1 & $2.22 \%$ & & & 1 & $1.05 \%$ \\
\hline $\begin{array}{c}\text { where is their impact on the man in the } \\
\text { street? }\end{array}$ & 2 & $4.44 \%$ & & & 2 & $2.11 \%$ \\
\hline address a few number of the Internet users & 3 & $6.67 \%$ & & & 3 & $3.16 \%$ \\
\hline $\begin{array}{c}\text { poor economic situation, the high cost of } \\
\text { living }\end{array}$ & 2 & $4.44 \%$ & & & 2 & $2.11 \%$ \\
\hline people's ignorance & 3 & $6.67 \%$ & & & 3 & $3.16 \%$ \\
\hline $\begin{array}{l}\text { security reasons and the public are not } \\
\text { convinced of these movements' usefulness }\end{array}$ & 2 & $4.44 \%$ & & & 2 & $2.11 \%$ \\
\hline Total & 45 & $100 \%$ & 50 & $100 \%$ & 95 & $100, \%$ \\
\hline
\end{tabular}

$\chi 2=37.65, . \mathrm{p}<0.05$ 
Reasons for the Transformation of the Egyptian Political Movements to Digital Phenomena Confined in Cyberspace "Sometimes"

Those who said "no" identified 16 reasons why the Egyptian political movements did not convert to digital phenomena, as follows:

Table 8

Reasons for the Egyptian Political Movements Did Not Convert to Digital Phenomena

\begin{tabular}{|c|c|c|c|c|c|c|}
\hline \multirow{3}{*}{ convert to digital phenomenac } & \multicolumn{4}{|c|}{ Sample } & \multirow{2}{*}{\multicolumn{2}{|c|}{ Total }} \\
\hline & \multicolumn{2}{|c|}{ Specialists } & \multicolumn{2}{|c|}{$\begin{array}{c}\text { Movements } \\
\text { Members }\end{array}$} & & \\
\hline & \# & $\%$ & $\#$ & $\%$ & $\#$ & $\%$ \\
\hline $\begin{array}{c}\text { They have turned into a tangible reality that } \\
\text { has an impact on the Egyptian street }\end{array}$ & & & 2 & $5.71 \%$ & 2 & $3.92 \%$ \\
\hline $\begin{array}{l}\text { they have activities and initiatives in the } \\
\text { Egyptian street }\end{array}$ & & & 2 & $5.71 \%$ & 2 & $3.92 \%$ \\
\hline $\begin{array}{l}\text { today youth are the most widely category } \\
\text { who use of these media }\end{array}$ & 2 & $12.50 \%$ & 4 & $11.43 \%$ & 6 & $11.76 \%$ \\
\hline $\begin{array}{l}\text { change in regime dialog and the people } \\
\text { rallying around those movements }\end{array}$ & & & 1 & $2.86 \%$ & 1 & $1.965 \%$ \\
\hline $\begin{array}{c}\text { cyberspace is accompanied with the } \\
\text { existence of street powers (strikes \& } \\
\text { demonstrations) }\end{array}$ & & & 4 & $11.43 \%$ & 4 & $7.84 \%$ \\
\hline $\begin{array}{c}\text { they are satisfied only with slogans without } \\
\text { deeds }\end{array}$ & 2 & $12.50 \%$ & 3 & $8.57 \%$ & 5 & $9.80 \%$ \\
\hline $\begin{array}{l}\text { they helped in increasing the activists' } \\
\text { effectiveness and communication with } \\
\text { public powers }\end{array}$ & & & 5 & $14.29 \%$ & 5 & $9.80 \%$ \\
\hline $\begin{array}{c}\text { are not confined to cyberspace but also they } \\
\text { spread to the rest of the media and the } \\
\text { Egyptian street }\end{array}$ & 3 & $18.75 \%$ & 6 & $17.14 \%$ & 9 & $17.65 \%$ \\
\hline the increasing numbers of these media users & & & 3 & $8.57 \%$ & 3 & $5.88 \%$ \\
\hline $\begin{array}{c}\text { there are movements came down to the } \\
\text { streets and managed to strike through online } \\
\text { invitations }\end{array}$ & & & 2 & $5.71 \%$ & 2 & $3.92 \%$ \\
\hline they currently use all electronic media & & & 3 & $8.57 \%$ & 3 & $5.88 \%$ \\
\hline are still unknown and weak & 4 & $25.00 \%$ & - & & 4 & $7.84 \%$ \\
\hline rely only on electronic media & 2 & $12.50 \%$ & - & & 2 & $3.92 \%$ \\
\hline they do not actually exist & 1 & $6.25 \%$ & - & & 1 & $1.96 \%$ \\
\hline $\begin{array}{c}\text { for social, technological, and political } \\
\text { reasons }\end{array}$ & 1 & $6.25 \%$ & - & & 1 & $1.96 \%$ \\
\hline $\begin{array}{l}\text { the poor economic situation and the high } \\
\text { cost of living }\end{array}$ & 1 & $6.25 \%$ & - & & 1 & $1.96 \%$ \\
\hline Total & 16 & $100,00 \%$ & 35 & $100,00 \%$ & 51 & $100,00 \%$ \\
\hline & & & & & & \\
\hline
\end{tabular}

$\chi 2=25.00, . \mathrm{p}<0.05$ 
Table 8 shows one fourth of the specialists think reason those movements did not convert to digital phenomena was that they are still unknown, while $18.8 \%$ say they are not confined to cyberspace but also they spread to the rest of the media and the Egyptian street and $12.5 \%$ said today's youth are those category who use of these media most.

Of the movements members, $17.1 \%$ said because they are not confined to cyberspace but also they spread to the rest of the media and the Egyptian street they helped in increasing the activists' effectiveness and communication with public powers, and $14.3 \%$ said cyberspace is accompanied with the existence of street powers (strikes \& demonstrations), while $11.4 \%$ said it was because the youth of today use these methods most and because cyberspace is accompanied by a strong presence in the street.

Of the total sample, $17.6 \%$ said put they are not confined to cyberspace but also they spread to the rest of the media and the Egyptian street. and $11.8 \%$ said followed because the youth of today are the ones that use digital media most widely used of these methods with a percentage.

\section{Discussion}

- Hypothesis 1: The first hypothesis states that "There are statistically significant differences between political movements' members and media specialists in the efficient use of new media ". There are significant statistical differences between specialists and members of movements in the efficiency of the use of new methods.

- Hypothesis 2: The second hypothesis states that: "There are statistically significant differences between political movements' members and media specialists in the effectiveness of new media." This hypothesis is confirmed.

- Hypothesis 3: The third hypothesis states that" There are statistically significant differences between political movements' members and media specialists in the ability of new media means in making change in developing countries. This hypothesis is confirmed.

In all three cases, movements members rate new media higher than the specialists do.

The author is an assistant professor and chair in the Media Education Department at Mansura University in Egypt. 
Notes for News Coverage of Environmental Risks: Subjective Knowledge, Personal Efficacy and Perceived Usefulness of Different Media

- http://www.taghyeer.net/news/details.aspx?id=e2765289-4d0e-416a-81d1$1077 \mathrm{c} 6 \mathrm{db} 61 \mathrm{fe}$

- http://www.taghyeer.net/news/details.aspx?id=e2765289-4d0e-416a-81d1$1077 \mathrm{c} 6 \mathrm{db} 61 \mathrm{fe}$

- Nasr ,Mohamed Hosni, blogs and supports the expression of pluralism in the Arab world, Egyptian Journal of Public Opinion Research, Public Opinion Research Center, Faculty of Information, Cairo University, Volume VIII, Issue III, July-September 2007

- Fadel Abdel Sabour, "Egyptian Blogs on the Internet" Egyptian Journal of Public Opinion Research - Faculty of Information - Cairo University - Volume 9 - Issue 2 - (July / December 2008): 228-229

- Lynch "Blogging" Arab Media \& Society, 2007: 10-11

- http://www.taghyeer.net/news/details.aspx?id=e2765289-4d0e-416a-81d1$1077 \mathrm{c} 6 \mathrm{db} 61 \mathrm{fe}$

- http://harakamasria.org/

- http://www.6april.org/

- http://www.6april.org/

- http://www.taghyeer.net/ 